Historic, Archive Document

Do not assume content reflects current scientific knowledge, policies, or practices. 



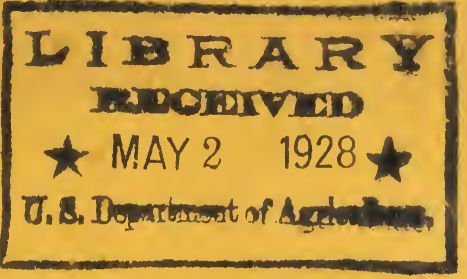

A

Hobby

That

Grew

.. 1928 



\section{PRICE LIST 1928}

\section{Lacona}

Gladiolus Gardens

A HOBBY THAT GREW

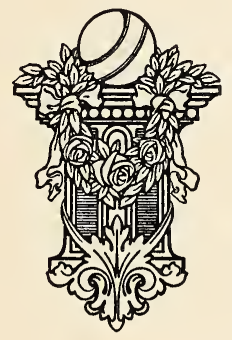

LACONA, NEW YORK 



\section{Lacona Gladiolus Gardens 1928}

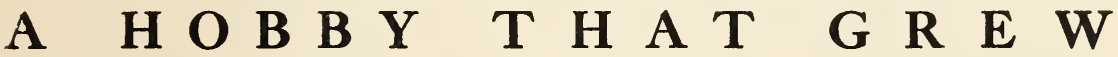

\section{Introduction ...}

A GIN I want to thank my customers for the nice business they gave me last year and I want to take this opportunity to acknowledge the nice letters of appreciation, many of which $I$ am afraid I did not answer personally. I never do seem to be able to sit down and answer letters unless it is something that does demand an immediate answer, especially is this true if there are Glads to plant, or look at, or harvest.

I have not tried to paint word pictures of the varieties listed. I am quoting in three sizes, $A, B$ and $C$. $A-1 \frac{1}{4}$ inches and all larger; $B-3 / 4$ to $1 \frac{1}{4}$, and $\mathrm{C}$-under $3 / 4$ inches. I find this grading for all practical purposes to be the equal of any and certainly more convenient than numerous closer grades. A size will give, generally speaking, the larger spikes and the earlier bloom. B size will give good bloom and usually better increase than A, and $\mathrm{C}$ will give a little bloom and good increase. Kindly state the size desired when you order.

\section{Order Early}

Many varieties listed I can supply by the thousand and many others I can only supply a few bulbs, so if you wish to avoid disappointment through my inability to supply some part of your order, the sooner your order comes in the better. You will note that some varieties are listed in only one or two sizes. That usually means that I am sold out on the other sizes or at least haven't enough of them to offer.

\section{Prices}

There seems to be no such thing as a standard price on any variety of gladiolus. Each grower follows his own conception of what he should get for them when making prices and I am doing the same thing. Doubtless my price is a little higher than some and I know it's lower than many. I believe that, taken as a whole, my prices are as low as any reliable grower can make and continue in the business year after year, correcting his mistakes, giving service to his customers and making both ends of his gladiolus business meet. I don't want to insinuate that a man who offers bulbs for less money than my prices may not give you just as good value and service as I do, but it has been my experience that while it isn't necessary to pay the excessive prices sometimes asked, it is, in the end, usually more satisfactory to pay a fair price than to buy 'way under value.

\section{Quality of Bulbs}

I believe every bulb offered to be true to name. All are of my own growing and except for a few large bulbs grown in my garden each year, they are all grown on new soil each year, so that the possibility of their being mixed through cormels or small bulbs living through the winter is 
obviated. I will refund the money or replace bulbs that do not prove true to name. My bulbs have been inspected officially and given a clean bill of health and I can furnish certificate to that effect to all states or countries requiring it.

\section{Northern New York Bulbs}

One feature that I don't believe any of us give enough attention, is the locality in which the bulbs that we buy are grown. I have had many years experience in buying, planting, and selling all kinds of farm seeds. Speaking generally, the shorter the season and the more rigorous the climate in which seeds are grown, the greater the tendency toward vigor and early maturity in the plants resulting from the planting of those seeds anywhere. Clover seed from Southern Europe is almost a failure when planted in the northern part of the United States. Seed corn of the same variety planted for a few years in the South will mature much later than the same seed corn grown in the North. I have bought Pennsylvania grown seed corn, raised my own seed from it and after a couple of years gotten more of the same corn from Pennsylvania, planted it beside that which I raised myself and found it ten days later to mature. I have bought gladiolus bulbs grown in a climate of practically no winter, and while they gave me excellent bloom the first year, they didn't amount to much after that until the cormels raised from them came into bloom. I noticed an article in The Bulletin some time ago in which a Pennsylvania grower says in effect, "My best results were obtained from Northern New York bulbs." Lacona is certainly Northern New York; and by the way, I want to invite every one of you who may be going through to the Thousand Islands, the Adirondacks, or anywhere else through the North Country, to stop and see our Glad gardens next summer.

\section{Terms}

The Glad business is a hobby with me. I look after the details of it myself. Frankly, I don't dare keep books on it because I know that if I did it would be in red ink all the while, but the dividends it pays in real pleasure are unbelievable, and the friendships that I have made through the gladiolus are priceless. But I don't keep any books on it and I won't be bothered with open accounts; so I must ask you to send a check with your order and if I can't fill it your money will be promptly returned.

\section{Postage}

I pay postage on all orders at single bulb or dozen prices and all orders on $\mathrm{B}$ and $\mathrm{C}$ sizes. A-size bulbs ordered at the per hundred price should be added 12c per hundred for the First and Second Zones; 20c for the Third; $35 \mathrm{c}$ for the Fourth; 50c for the Fifth; 65c for the Sixth; $81 \mathrm{c}$ for the Seventh, and $96 \mathrm{c}$ for the Eighth Zone. Tell your postmaster that you have some coming from Lacona and find out what zone. This applies only to A size bulbs ordered at hundred prices.

\section{Time of Shipment}

Unless otherwise ordered, bulbs will be shipped in March or April when the weather is such that there seems no danger of freezing.

\section{Wholesale}

If you wish to buy bulbs or cormels by the thousand, I'll be pleased to quote you. Write me what and how many you want; sizes A, B, C, or cormels, and if I can supply them I will be glad to quote a price that in most cases will be attractive; but don't ask for them graded in any way other than those mentioned above: A, B, C, or cormels. 


\section{Cormels}

I get many inquiries for cormels; anywhere from a dozen to a bushel and I am willing to sell them of almost any variety listed. However, unless you have had experience in growing bulbs from cormels, I don't recommend your buying them.

\section{Substitution}

I make absolutely no substitution wichout your permission, but I would appreciate permission to substitute as to size, if necessary.

\section{Arrangement}

Last year I tried to arrange the list alphabetically like a telephone directory, which would bring Mary S. Burke under the B's instead of under the M's. Never again! I couldn't find them in my own catalog myself, and so this year I am listing alphabetically but starting with the first letter of the name, and you will find Mrs. Doctor Norton under the M's; Joseph Field under the $J$ 's and Virginia Hale under the V's, etc.

\section{Cultural Directions}

The gladiolus is so easy to grow that it seems almost absurd to encumber this list with cultural directions. Just plant them out in the sun where potatoes or corn would grow well. They will stand fertilizer in any amount or in any form that wouldn't injure your potatoes. Don't be afraid of doing too much cultivating or hoeing among them. That's about all there is to it. If you desire more complete cultural directions just say so on your order and I will inclose them.

On our soil-and I believe this is true with most soils-I find the best results obtained by fertilizing with well rotted stable manure plowed well under in the fall and supplemented with a mixture of hard wood ashes and raw phosphate rock in the rows at planting time. A strong alkali soil might give better results with acid rock instead of the raw rock, but on our soil which is apt to be slightly acid I get wonderfully good results with raw rock.

\section{Suggestions}

To those of you who want to buy good varieties, to whom the flower itself means more than its name or its newness, I want to suggest that it isn't necessary to pay a long price in order to get a good Glad. Some of the medium priced varieties are, generally speaking, as satisfactory as some of the newer and much higher priced ones, so I am taking this opportunity of suggesting some medium priced varieties-and by that I mean not over $50 \mathrm{c}$ per bulb-that will give the average flower lover as much pleasure as those costing many times as much. The real dyed-in-the-wool connoisseur will buy the higher priced varieties and get his money's worth and still have no more beautiful flower garden than the fellow who sticks to the tried and true kinds that are a little older.

In the reds, Crimson Glow, Beacon Flame, Black Joe, Majestic (Cowee's Scarlet Wonder), Neoga and good old Governor Hanley, are good. Look over the reports of the gladiolus shows for the past two or three years and you will find most of the winners in the red classes in this list. I believe Crimson Glow has won oftener at all shows big and little than any other one red. In the whites, Europa, Carmen Sylvia and Imperator are hard to beat and likewise have, generally speaking, been the winners at the shows, big and little. In pinks there are a world of good ones. Mrs. Armsby, Mrs. Leon Douglas, Jennie Lind (what more beautiful Glad than Jennie Lind?), Giant Nymph, Virginia Hale, Adeline Kent, Marietta, Sophia Fischer, Superba, Catherine 
Coleman;-you couldn't go wrong on one of them. What better dark red than Persia, and it isn't high priced. In the yellows there are Gold, Souvenir, Ethelyn. Don't despise them because they are cheap. If you like the striking blotched ones, what blotched varieties are bigger, better or more striking than Mme. Mounet-Sully, Emile Lemoine, Jean Du Tallies, Eugene Lefebvre. I don't care what they cost. Among the dainty creams and tints, what is handsomer than Fern Kyle, Marie Kundred or Miss T. Rose, and in the dark reddish purples and violets there are Purple Glory, Anna Eberius, Heliotrope, Exquiaite, Rosenel and Nellie Grant.

The above is not a comprehensive list but it's just an idea of wonderfully good Glads for very moderate prices and possibly to serve as a suggestion to those of you who want a beautiful flower garden for a little money. I should have added some novelties, which on account of their different coloring or other features make them especially desirable. Casa Blanca, Louis Hemoine, Leopard and Romance would come under this heading.

\section{Mixed Bulbs}

There is no way of avoiding a certain number of mixed bulbs which come from those accidentally mixed, a surplus in some named varieties and more or less seedlings. A large percentage of these I sell wholesale but each year some of my customers want some of these bulbs for their own planting. I consider it an excellent mixture and decidedly more satisfactory than most mixtures. One gentleman after growing a few of them two years ago bought 2.000 for his own planting last year and my sales on this mixture for individual planting are steadily increasing. A-size, good, plump, well cleaned bulbs- $\$ 2.50$ a hundred, postpaid, or $\$ 15.00$ a thousand, F. O. B. Lacona.

\section{Key}

The following is a key to the abbreviations used:

C.-Cowee. Col.-Coleman. D.-Diener. G.-Goodrich. Gf.-Groff. K.Kundred. Kp.-Kemp. Kel.-Kelway. L.-Lemoine. M.-Metzner Floral Co. Prest.-Prestgarde. Vil.-Vilmoine. Z.-Zeestratin. Prim.-P'rimulinus type. Prim.-Hybrid-showing Primulinus blood. P. G.-Primulinus Grandiflorafl Gf.-Grandiflora. 


\section{Varieties-Blooming Size Bulbs}

ADELINA (Kel)-Tall, Rose pink; rated in 1926 in the nineties, by Gersdorf, A. G. S. scale.

ADELINE KENT (D) Ruffled-Heavily ruffled, delicate light rose pink; cream throat with Tyrian rose markings. Many flowers open. A beauty.

AFTERGLOW (Cowee)-Tall, large flowers, salmon mon scarlet with purplish rose throat. A beautiful Glad.

AFTERGLOW (Z)-Prim. Hybrid. Deep pink. Tall, vigorous plant with plenty of bloom.

AGRICOLA (G)-Immense flower and plant; variegated pink and white. A favorite with visitors to my gardens.

ALICE-Brilliant orange salmon with lighter throat. Supply limited.

ALICE TIPLADY (K)-P. G.-Orange saffron. Exceptionally nice flowers and spike. Very desirable for both garden and cut flowers.

ALOHA (M)-Cherry Scarlet; canary yellow throat. Tall, large flowers.

ALPINE TREASURE (M)-Lilac over white ground; large flowers and many out at once. Very desirable. Rather early.

AL SHIRA (K)-Large; dark wine red; darker in the throat; distinctive.

ALTON (K)-Heavily ruffled; orange salmon. Flame red lip. Unusual color.

AMERICAN BEAUTY (D)-American Beauty color; cream throat. Many blooms open at once; rather closely placed on the spike.

ANNA EBERIUS (D)-Deep Rhodamine purple; large flowers. About the best of its color for commercial use.

ANTHONY ZONKER (K)-Dark salmon; velvety red blotch. Many large blooms open at once. Ruffled.

APEX (Bill)-Each year this veriety is making many new friends. Clear, deep salmon pink with darker center; a giant plant and flower. The foliage is a wonderful green and seems to stay green long after the frost has turned most varieties brown. A letter from one customer who bought Apex last year pronounces it "the best thing in his garden. Spikes 5 feet tall with plenty of 5 -inch bloom."

APPLE BLOSSOM-(Pfitzner)-Tall apple blossom pink; many open, large blooms; good.

ARBUTUS (C)-Beautiful arbutus pink. Large wide open bloom; early. When this becomes more common I believe it will be very largely grown for cut flowers.
1

A $\$ .15$

B $\quad .10$

12

A $\quad .15$

1.50

1.50

1.00

$\mathrm{A} \quad .10$

1.00

A $\quad .10$

1.00

A $\quad .10$

1.00

A $\quad .20$

A

.75

A $\quad .10$

1.00

A $\quad .10$

1.00

$\mathrm{A} \quad .10$

1.00

B $\quad .75$

A $\quad .20$

A $\quad .10$

1.00

A $\quad .20$

2.00

A $\quad .25$

1.50

1.00

A $\quad .35$

$\mathrm{A} \quad .15$

1.50

B $\quad .10$ 
ARISTOCRAT (Bill)-Strong, massive spikes of pale saffron, flaked orange. Very distinctive variety.

A. W. HUNT (Christie)-Large orange red.

BEACON FLAME (Vondel)-Deep red; large blooms and quite early.

BEATRIZ MICHELENA (D)-P'each red, overlaid with fiery orange. Large flowers, many out at once. Regarded very highly.

BETTY JOY (Bill)-Soft, creamy white, suffused LaFrance pink. A very attractive spike and many good sized blooms open at once.

BIG BLACK (K)-A giant dark red.

BLACK JOE (P) -A very dark crimson, selfcolored. One of the very best dark reds.

BLUE JAY (Gf)-Still one of the best of the socalled blues. A bluish gray with throat markings. Good sized flower, strong and vigorous.

BUTTER BOY (K)-Prim. Hybrid-Clear yellow. Strong plant with long spike and large flowers. Considered one of the best yellow Prims.

BUTTERFLY (K) Prim. Hybrid-Large, butterfly shaped blooms on a rather tall, slender stem.

BYRON L. SMITH (K)-White, delicately suffused light mallow purple. Throat Marguerite yellow. "The orchid gladiolus."

CAMEO (M)-Coral, partially overlaid with darker pink. Large flowers, wonderful spike; many flowers out at once: occasionally the whole spike. Grow Cameo in your garden.

CANICULE (Souchet)-Bright red with white blotch. Large flowers. Decidedly worth while. Slow to increase.

CAPTAIN BOYNTON (Boynton)-White suffused lavender. Deep lavender blotch.

CAPTAIN FERBER (Lemoirie)-Plum violet; large flowers. Decidedly different.

CAPTAIN MASSOINET (Lemoine)-Withdrawn this year to increase stock.

CARMEN SYLVIA (P)-Large, early white. Very slight violet markings deep in the throat. About the best early pure white.

CASA BLANCA (Lemoine)-White with throat attractively marked by distinct, delicate, almost parallel lines of lilac. Large flowers.

CATHERINE COLEMAN (Col)-LaFrance pink, blotched Amaranth purple. Wonderful spike and bloom. One of the most consistent prize winners at all the shows. bloom. Early to midseason. 
CHOSEN QUEEN (M)-Giant plant and flower; rose cerise. Lower petals deep rose. A wonderful Glad.

\begin{tabular}{lrr} 
& \multicolumn{1}{c}{} & \multicolumn{1}{c}{12} \\
$\mathrm{~A}$ & .25 & 2.50 \\
$\mathrm{~B}$ & .15 & 1.50 \\
$\mathrm{C}$ & & .75 \\
$\mathrm{~A}$ & .10 & 1.00 \\
$\mathrm{~B}$ & & .75
\end{tabular}

CINNAMON BEAR (K)-Ruffled-Deep violet red, large blooms.

COLANTHA-This variety was a disappointment to me this year and I have withdrawn it, temporarily at least. Whether this was just a seasonal condition or whether this variety has actually deteriorated I do not know. However, to those who bought Colantha of me last year, I will say that if it also proved a disappointment to you, select bulbs from this catalog to the amount that you paid me for Colantha and I will be glad to send them to you without cost.

COLONIAL (M)-Pale lilac pink and golden yellow. Large and early.

CONSPICUOUS-A so-called blue with a yellow throat. One you will see clear across the garden. Looks like a big blue pansy.

COURONNEMENT (Brunelet)-Tall, deep red with blotch.

COWEE'S SCARLET WONDER (Gf)-Mammoth deep pure scarlet flowers on tall, straight stems.

CRIMSON GLOW (Betcher)-Scarlet red. One of the very best reds. Large blooms.

DAWN (Gr)-Giant spike and flower. Early, bright pink. I like it.

DEUTCHLAND (Graetz)-A good pink.

DIANA-See Empire.

DISTINCTION-Very tall, early, dark, purplish maroon.

DIXIE (K)-Very deep, almost black, red; early. A decided improvement on Empress of India.

DOCTO'R ELKINS (K)-Large, showy flowers, white with a large blotch of deep lilac blue. A novelty of decided merit.

DOCTOR F. E. BENNETT (D)-Vivid scarlet, large flowers. Many out.

DOCTOR NEELEY (K)-Tall; blush pink, canary yellow throat. Fine.

DOCTOR VAN FLEET (K. P. G.)-Tall, beautiful rose pink with a cream throat.

DOROTHY WHEELER (K) Prim. Hybrid-Large, well opened flowers of delicate rose pink on a tall, graceful stem. One of the best in its class.

DORIT (K)-Rose lilac over white ground. Large flowers. Greatly admired.

$\begin{array}{lll}\mathrm{A} & .20 & 2.00 \\ \mathrm{~B} & .15 & 1.50\end{array}$

$\mathrm{A} \quad .10 \quad 1.00$

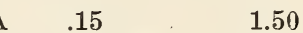

B $\quad 1.00$

$\begin{array}{lll}\mathrm{A} & .15 & 1.50\end{array}$

B $\quad 1.00$

C $\quad .60$

$\begin{array}{lll}\mathrm{A} & .10 & .80\end{array}$

B $\quad .50$

$\begin{array}{lll}\mathrm{A} & .10 & 1.00\end{array}$

.60

$\mathrm{A} \quad .25$

$\mathrm{A} \quad .10$

1.00

$\begin{array}{lll}\mathrm{A} & .10 & 1.00\end{array}$

$\begin{array}{lll}\mathrm{A} & .10 & 1.00\end{array}$

A $\quad .15 \quad 1.50$

B $\quad .10 \quad 1.00$

A $\quad .40$

B $\quad .25$

$\mathrm{A} \quad .10$

1.00

.75

$\begin{array}{lll}\mathrm{A} & .10 & 1.00\end{array}$

B $\quad .75$

$\begin{array}{lll}\mathrm{A} & .10 & 1.00\end{array}$

B $\quad .75$

$\begin{array}{lll}\mathrm{A} & .10 & 1.00\end{array}$

DREAM (K)--Large, massive bloom. Deep salmon A .20 red with large blotch.

DUCHESS OF YORK (Holland)-Large purple blue flowers with many out. Probably the best variety to use with the many fine yellows. A really vigorous blue. 
EDOUARD GRIEG (Lemoine)-Bright rose with A $\quad 1.25$ brilliant Amaranth blotch. Tall spike, large flowers.

E. G. HILL-A true pink with cream throat. An exceptionally nice Glad. It has exceptional commercial value.

E. J. SHAYLOR (K)-Deep rose pink. Long spike, many large flowers.

ELIZABETH R. LIABLE (Liable)-Tall spike with very large, creamy yellow blooms, lightly tinted pink. A beautiful bloom but not a really vigorous grower and a poor propagator.

ELIZABETH TABER (Hinklis)-Rosy pink over white ground with dark crimson blotch. Very large flowers, long, graceful spike and very early.

ELORA (Burbank)-White with yellow throat, blotched carmine. Large flowers and very early.

EMILE AUBRUN (Lemoine)-Deep, smoky pink with large, cherry red blotch. Very large flowers, well arranged on a tall, straight spike, with many open at once. An outstanding variety.

EMILE LEMOINE (L)-Clear, pale lavender with deep violet blotch. Tall spikes and large flowers. Decidedly worth while.

EMPIRE-One of the very best early bright reds.

ETHELYN (Fischer) P. G.-Very tall spike; large orange yellow flowers, many open. The best of its color and one of the greatest of Fischer originations. Mark it "must have".

EUGENE LEFEBVRE (Lemoine)-Deep pink, blotched Amaranth purple. Tall spikes, large flowers. Excellent variety.

EUROPA (Pfitzner)-Pure white, large flowers. Many open at once. P'robably the best exhibition white in existence.

EXQUISITE (K)-American Beauty rose color. A strong plant with many large flowers out at once. Very desirable.

FALLEN LEAF (M)-A combination of smoky pink and dull smoky lavender that's hard to describe. Strong plant and tall spike. Good sized flowers, usually well arranged.

FASTIDIOUS (Bill)-P. G.-Large, open flowers; delicate shell pink. Nice spike. Vigorous grower; excellent cut flower. One of Bill's best.

A

B

.10

1.00 .75

$\mathrm{A} \quad .10$

$\mathrm{A} \quad .50$

A $\quad .10$

$\mathrm{A} \quad .10$

A $\quad 1.00$

10.00

B $\quad .75$

7.50

4.50

2.50

1.75

1.00

1.00

2.50

1.75

1.00

2.00

1.50

1.00

1.50

1.00

1.50

1.00

A $\quad .1 .00$

A $\quad .15$

1.50

1.00

.70

1.75

1.25

.75 white flowers with slight mark of Amaranth purple in the throat. Wonderful spike and bloom. An exhibition variety.

FLORA-Clear, light yellow. Large flowers. A strong grower. 


\section{My Own Introductions-1928}

I $\mathrm{N}$ OFFERING for the first time the following originations of my own, I am trying to paint as true a picture of the varieties as I can, all the while bearing in mind that they are my own originations and that I am naturally predisposed in their favor. I have in the past so many times ordered bulbs with glowing descriptions and been disappointed in the bloom that I am trying to guard against your having a like experience with any of these. So the first part of the description of each variety is the Field Notes that I have taken, which are to a large extent the color from Ridgeway and certain actual measurements. The remarks that I have added to these few notes are my own impressions. I have tried to make them conservative. As I read it over, I can't see anything very conservative about my remarks regarding Mother Machree. I have been enthusiastic over this 204-E ever since the first time I saw it bloom, and each time I see it I am more enthusiastic than before. Other people who see it seem to be equally enthusiastic and I don't believe it's all out of politeness. Somehow, I just can't help letting words run wild when I get to talking about Mother Machree.

Last year I sent out a few of my seedlings under number to some of my old customers whom I knew were growing many of the better, newer things, with the request that they report back to me their impression of these seedlings. I find these reports decidedly valuable. Some good ones were not sufficiently impressive so they will never be marketed, and of others they only confirm the good opinion I had. This year during the blooming period I selected about a hundred different ones, that I have been growing under number, as being worthy of further consideration and I am offering you now twelve of these, of my own selection, for the nominal price of $\$ 2.50$, with the understanding that you will plant them, labeled as you receive them, and after they have bloomed report back to me your opinion of each of them. I will keep a list of the numbers that you receive (they are all under number) and will inform you when any of them are named. I have been advised against doing this on the theory that I would lose control of the stock and the value be lessened when they were introduced, but even so, I would rather do it than to introduce varieties that would not meet with the approval of my customers. Not over twelve to a customer and not sold except with other orders or to somebody who has ordered before.

PRICES-On these introductions means for bulbs 1 inch or larger, as near the size you ask for as we can send you.

\section{Mother Machree (204-E)}

Unfortunately, I have no field notes on Mother Machree. That was one seedling which appealed to me so much that I never even stopped to make notes on it. Mother Machree was the winning seedling in Exhibition Class and won the Antisdale Special for best seedling at the American Gladiolus Society's Show at Hartford, August 1927. In their report of the show, Horticultural spoke of it as "the outstanding spike of the show". Charles F. Gersdorf in his report of the show in the Bulletin says, "Mother Machree-a beautiful name for a beautiful Glad. A massive spike; number of blooms open, large; in color a light gray with a few flashes of Grenadine pink. A bloom to rave over, as many of us did". Alfred M. S. Phidehan of Cornell University in his article in the Bulletin, entitled "Six Hundred and FiftyThree Varieties Studied at the A. G. S. Show in 1927", in mentioning some of the outstanding varieties says this: "And a new one which we will hear more of, a seedling introduced by Floyd Stevens, Mother Machree. The color is vinaceous lavender shading to deep vinaceous lavender toward the outer end of the petals. Tips of petals flecked carnelian red; throat cream with a line of light jasper red, or at least that is the color the way I got 
it". Gersdorf says it is a "gray with a few flakes of grenadine pink" and most people call it "that big smoky one". It's an unusual color; one that I never before saw in a gladiolus. A large flower, five inches in diameter; of wonderful substance and lasting quality; tall, straight spike with plenty of bloom, six or eight out at once. Very vigorous grower; gives good cormel increase and cormels germinate well. Nearly every Glad lover who sees it is enthusiastic over it and I believe that as the stock becomes available it will be very widely grown. The facing and arrangement of the blooms are excellent. In fact, it is a finished gladiolus in every way. There are many good pinks, and whites and reds, and yellows, but in its color Mother Machree has no competitor. To the hybridizer I would say that I used Mother Machree this year and it is an excellent seed parent. Whether or not it will transmit its wonderful color characteristics remains to be determined. I sold one-half the stock of Mother Machree to Elmer E. Gove, and as a part of the consideration and agreement of sale, no bulbs of any size are to be sold by either of us at less than the advertised price or to be given as premiums and no cormels are to be sold at any price for two years. To say nothing of the pleasure of growing this beautiful Glad, I believe there is no better gladiolus investment today than one or more bulbs of Mother Machree. $\$ 100$ each for any size bulb.

\section{Charles G. Thomas (201-B) (Field Notes)}

Pinard yellow, practically a self color. Sometimes a very slight flecking of pale pink at the tips of the petals. $4 \frac{1}{2}$ inches in diameter; five or more blooms open at a time. Edges of petals rolled and slightly crinkled, giving a distinctive appearance. Long, well shaped spike. Spaced and arranged attractively. P. G. type, no hood. One of the earliest.

A seedling from a big, husky yellow G. F. and Bill's Gladdie Boy. Mr. Thomas was in my garden this summer and saw and admired this yellow seedling, and you who know him well understand my gratification when he allowed me to name it as I did. The size, earliness, attractiveness of form and color and the fact that it is a vigorous plant and gives good increase make this variety a very desirable addition. Only a few bulbs to offer this year.

$\$ 10.00$ each.

\section{Damascus (27อ-B)}

\section{(Field Notes)}

Argyle purple and Hellebore red, beautifully overlaid and blended, tinting to lighter tones of the same color in the center of the bloom. Blotched Tilleul buff, which in turn is stippled and plumed Bordeaux. The effect of the bloom is a rather dark but bright bluish tinted ashes of roses. $4 \frac{1 / 2}{2}$ inch bloom, 5 or 6 out. Arranged in a medium wide double row with rather wide spacing. Long, straight spike and stem. Edges of petals slightly rolled. Wonderful in combination with yellows, especially the light yellows.

This description gives the impression of a dull coloring, but it is not dull. I sent out two of these bulbs last year. One of them went to a grower in Canada who has practically all of the better stuff. I quote from his letter. "I must drop you a line to congratulate you on Seedling 275-B. This variety was planted rather late, due to the difficulty of planting and labeling 1,600 different varieties; so it didn't bloom until September 10th. A second spike bloomed later and was used as the chief color note in a bridesmaid's spray with autumn foliage, and created a sensation. The flower was of fair size, blue in the open becoming redder as it opens inside. The throat is a velvety ruby. I found the color combination delightful and the spike and texture excellent. It is the best of all varieties approaching it in color effect that I have grown. It's better than Oriental Gem and I prefer 
it to Fallen Lreaf. I presume you will name and offer this seedling as an outstanding novelty." The other bulb I sent out to a lady known to all who attend our National Shows. I quote from her letter regarding it. "I like the bloom very much. The shape of the flower is good; so is the coloring." This variety will never approach Mother Machree as an exhibition flower, but it is one that I believe will meet general favor with Glad lovers and has an excellent future commercially. Increase and germination good. $\$ 5.00$ each.

\section{Tritomia (297 A-P) \\ (Field Notes)}

Flesh pink with, deep in the throat, a scarlet overlay edged Empire yellow. $41 / 2$ to 5 inches in diameter. Four or five open. Tall, straight spikes, slender, wiry stem; a good number of flowerets nicely arranged. Very early. This was planted this year a couple of days after a row of Hallie that I used as a check on blooming time and it bloomed better than a week before the first Hallie opened. It is a seedling from Prince of Wales, but earlier and a much stronger grower, with excellent foliage. It is a well finished gladiolus in every sense. I quote from a letter from a gentleman in Michigan who grew this seedling this past season. He says quite a bit about it. "Fine shape." "Buds like beautiful rose buds." "Texture fine." "Very attractive." "I liked this seedling very much and in my judgment it was the equal of many that are considered very highly among the trade." I believe it is valuable commercially and as a cut flower. $50 \mathrm{c}$ each, $\$ 5.00$ per dozen.

\section{Reflection (297 A-U) (Field Notes)}

White, blotched bright scarlet red with a faint sheen of scarlet red on the center of all petals, appearing like a reflection of the blotch. $41 / 2$ to 5 inches. A good number out. Edges of petals crimped. Flowers of distinctive shape, arranged in a staggered row. Long, straight, slender spike and stem; petals are heavy and of good texture. Medium early. This is a distinctive and attractive gladiolus, an unusual and effective color scheme, one that has pleased all of our visitors and one that I believe will prove valuable in the garden and commercially. It is a thrifty grower and gives good increase.

$\$ 1.00$ each, $\$ 10.00$ per dozen.

\section{Mary McConnell (295-L)}

(Field Notes)

Spectrum red flecked carmine tinting lighter deep in the throat. Lower petals with an overlay of carmine. $4 \frac{1}{2}$ to 5 inches in diameter; 6 out; 18 to 20 on the spike besides a side spike. Velvety, attractive, well ruffled bloom. Strong spike and good arrangement. A seedling of Purple Glory. Strong grower. Gives average to good increase. Early to mid-season. $\$ 1.00$ each.

\section{Ramesis (295-H)}

(Field Notes)

Aster purple. Lower petals have a velvety overlay blotch of Pomegranite purple with a stippling of white 'way deep in the throat. 6 to $61 / 2$ inches in diameter; four out. Tall, straight, thin, spike with the blooms rather widely spaced in a staggered row. Wide open, very deep bloom, waved and slightly ruffled. P. G. or G. F.

This seedling of Purple Glory presents such a regal, Oriental splendor that Ramesis immediately suggested itself as a name. There are not enough 
blooms open at once to make it an exhibition flower and the deepness of the bloom and length of attachment to the stem handicap it as a commercial flower, but as a fancier's flower it is a wonder. When I first saw it I thought it was the most beautiful gladiolus I had ever seen, and the day I first saw it was after coming home from the A. G. S. show at Rochester a few years ago. I don't believe it has any future as a commercial variety, but I do believe it will please every fancier who grows it.

$\$ 2.00$ each.

\section{Little Sister (Prim E)}

\section{(Field Notes)}

Delicate Hermosa pink; lower petals delicately cream colored in the center. $3 \frac{1}{2}$ to 4 inches; 5 or 6 out at once. Tall, straight, thin spikes with lots of bloom. Excellent stem and arrangement. Very slight hood. Petals reflexed and slightly crimped.

To these Field Notes I want to add: Very strong grower; wonderful increase, early. This variety is very effective in mass. The delicate coloring and beautiful form make it worth while. Another thing to its advantage is its excellent keeping qualities. Mrs. Stevens used this for a bridal bouquet this summer which three days after, without any water, still presented a creditable appearance. I am offering this only in a dozen or more bulbs to a buyer because you want several spikes of this variety to fully appreciate it.

\section{Orange Smoke (Prim Q) (Field Notes)}

Bittersweet orange. Edges of petals flecked neutral red. Lower petals with light orange yellow deep in the center and light scarlet lines. The color effect is a smoky orange. Blooms $4 \frac{1}{2}$ inches in diameter, wide open, P. G. type. Slender stem, usually straight, with rather wide spacing. Rather attractive. $25 \mathrm{c}$.

\section{Sally (Prim K)}

Clear Empire yellow, tinting to Baryat yellow at the outer edges of the petals. Tips of petals flecked with tints of peach red. Petals reflexed. 4 to $4 \frac{1}{2}$ inches. Five out. Excellent arrangement. Tall, with stems usually straight. General appearance good. P. G. type. This is a very early variety, the first in my whole garden to bloom in 1927, beating by four days Tritomia, and Charles G. Thomas by just a week. Its earliness and attractiveness I believe give it decided commercial value. A strong grower with plenty of increase.

25 c.

\section{American Gladiolus Society}

Doubtless you are a member of the American Gladiolus Society. If you are not, membership, including the A. G. S. Official Bulletin, is $\$ 2.00$ for the year. You get a copy of the Bulletin monthly; are entitled to enter flowers in all shows under the management of the American Gladiolus Society; take part in the meeting, etc., etc. If you grow Glads, join the A. G. S. Send your $\$ 2.00$ to Roscoe Huff, Secretary, Goshen, Indiana. Or if you are ordering bulbs from me, you may send your $\$ 2.00$ on to me and I will attend to it for you. 
FLORENCE (Vil)-Bright lilac with white throat. Tall spike and many flowers. Decidedly good.

FORTUNA (Fischer) -A large, well finished flower of pink and cream. Beautifully blended. Nice spike.

GAY NOR (Col)-A nice rose red.

GENERAL DEWITT-Soft, flesh pink; excellent spike. P. G. type.

GIANT NYMPH (Col)-LaFrance pink with a creamy yellow throat. Large, wide open flowers, long spikes and a very vigorous plant. This variety will produce practically $100 \%$ salable spikes under almost any conditions and is, I believe, one of the most satisfactory pinks in existence.

GLADYS PATHE (D)-A big mallow purple.

GLENDALE-Dark American Beauty rose color. Good keeper.

GLORIANA-Golden salmon with a clear yellow throat. Wonderful color; tall spikes. A really good Glad.

GOLD (Hoeg)-Deep, clear yellow. Excellent spike and plant. A good number of flowers out. Just about the best commercial yellow.

GOLD DROP (K) Prim. Hybrid-A large flower, yellow with red markings in the throat.

GOLD EAGLE (Austin)-Clear, deep yellow. Very early. An outstanding variety.

GOLDEN BUTTERFLY (K) P. G.-Large, well opened, clear light yellow flowers. Especially attractive on account of the shape and arrangement of blooms.

GOLDEN DREAM (Groff)-Clear, deep yellow; tall and straight; a good number open. Its reflexing petals give it a beauty and distinction all its own.

GOLDEN GATE (K) Prim. Hybrid-A big yellow Prim with red markings. The whole spike and bloom have a lot of finish.

GOLDEN MEASURE-Tall, straw yellow. Very heavy spikes of large flowers. Too tall and awkward for a commercial value. Personally I like Gold much better.

GOLDEN VLIESS (European)-Clear bright yellow. Many good sized blooms out at once.

GOLIATH-Deep wine red; large open flowers. Well arranged.

GOVERNOR HANLEY (K)-Early, bright red. A ${ }^{\circ} .10$ Large flowers.

A $\quad .15$

A $\quad .10$ 
HARWINTON (White)-Very tall spikes of many medium sized, fuchsia colored flowers. Desirable on account of its bright, distinct color, and profuse bloom.

HAWAII (D)-Rose pink, lighter in the center. Fine spike, large flowers.

$\begin{array}{rrr}\mathrm{A} & .10 & 1.00 \\ \mathrm{~B} & & .75 \\ \mathrm{C} & & .50 \\ \mathrm{~A} & .25 & 2.50\end{array}$

HELIOTROPE (L)-Clear, deep, velvety violet Medium sized plant and flowers. This is especially desirable on account of its color, which I believe is the deepest and best violet yet brought out. 1 inch and larger bulbs.

IMPERATO'R (Heemskerk) - Creamy buds opening to enormous white flowers. Strong spike, vigorous plant; abundant foliage. One of the very best late whites.

INDIAN SUMMER (K)-Pinkish lavender. Strong spike with many large flowers opening at one time. Very late.

J. A. CARBONE (D)-Immense flowers of orange salmon, shading darker at the outer edge of petals. Many out at once.

JACOBA VON BEYERJEN (Holland)-Purple violet, self-colored. Strong plant with many large flowers open. An exquisite commercial variety.

JAP LADY (Hazg)-Bishop's purple with a darker velvety blotch in the throat. Nothing like it. One you should have. One inch or larger bulbs.

JEAN DU TALLIES (L)-Deep salmon with maroon blotch; tall spike; very large bloom. One of the best. Very distinctive in appearance.

JENNIE LIND (Hoeg)-Shrimp pink, deepening to geranium pink at tips of petals. Many out. I believe it is the most beautiful pink gladiolus in existence.

JEWEL (Z)-Prim. Hybrid-Beautiful salmon pink with clear golden yellow throat. Large, wide open flowers on a tall, well formed spike. Early.

JOE COLEMAN (K)-A strong, vigorous ruffled red.

JOHN F. LEWIS-P'inkish lavender. Large, well opened flowers on a very tall, well formed spike. A good Glad.

JOSEPH FIELD (D)-Dawn pink, lightly striped mallow pink and ruby. Creamy white lip. Very large flowers.

KITTY GRULLMANS (Grullmans)-Tall spike, large open yellow blooms overlaid with apricot at the edge of the petals. Early.

LACORDAIRE (L)-Early, bright red. Excellent blor $m$ and spike.

$\begin{array}{lll}\mathrm{A} & .50 & 5.00\end{array}$

$\mathrm{B} \quad .30 \quad 3.50$

C $\quad 2.50$

A $\quad .25 \quad 2.50$

$\begin{array}{lll}\text { B } & .20 & 200\end{array}$

C $\quad 1.00$

A $\quad .15 \quad 1.50$

B $\quad 1.00$

C $\quad .75$

$\mathrm{A} \quad .15 \quad 1.50$

B $\quad 1.00$

$\begin{array}{ll}\mathrm{C} & .75\end{array}$

$\mathrm{A} \quad .50$

$\begin{array}{lll}\mathrm{A} & .25 & 2.00\end{array}$

B $\quad 1.75$

C $\quad 1.00$

A $\quad .15 \quad 1.50$

B $\quad 1.00$

$\begin{array}{ll}\mathrm{C} & .75\end{array}$

A $\quad .10 \quad .80$

$\mathrm{A} \quad .10 \quad .80$

A $\quad .50 \quad 5.00$

$\begin{array}{lll}\text { B } & .35 & 3.50\end{array}$

$\begin{array}{lll}\text { A } & .40 & 4.00\end{array}$

$\begin{array}{lll}\mathrm{B} & .30 & 3.00\end{array}$

$\begin{array}{lll}\text { A } & .10 & 1.00\end{array}$

$\begin{array}{ll}\text { B } & .75\end{array}$

$\begin{array}{lll}\mathrm{A} & .10 & 1.00\end{array}$

B $\quad .75$

LADY BYNG (Gilchrist)-Shell pink. Well finished, refined appearance, vigorous grower; early. Five or six large blooms open at once. 
LA IMMACULIE-Tall, early clear white. An excellent early white.

LEOPARD (L) - A purple violet with a big yellow center. A novelty in color. Tall, strong plant. A variety that always attracts attention.

LEOTA (Coleman)-Geranium pink suffused rosedoree. Large, wide open flowers. Exceptionally pleasing color.

LONGFELLOW (Prest)-Very tall spikes, La France pink. Wide open flowers. One of the best.

LOS ALTOS (M)-Large flowers of a distinctive pink, hard to describe. Rather unusual.

LOUISE (Wright)-White suffused with phlox pink and phlox purple. Very large beautiful flowers. A good grower.

LOUIS HEMOINE (L)-Another striking novelty. Three inner petals pure yellow, the outer petals salmon striped with orange red. Good number of blooms out at once. Even more striking in color than old Mephistopheles.

LOVELINESS-Good spike; good sized fiowers of cream tinted pink. Plenty of bloom out at once. One of the best of the older sort.

LUCIE-Clear, light yellow. Very tall, strong grower, resembling Golden Measure in this respect.

MAHO'MET-Another desirable novelty. A deep pink heavily flecked and overlaid very much darker. A great favorite with visitors to the garden.

MAIDEN'S BLUSH-The standard florist's pink Prim. Early.

MAINE (Voss)-Pure white; shows faint yellow tints as it first opens. Good form and substance. A fine variety.

MAJESTIC (Groff)-The same as Scarlet Wonder. Mammoth deep pure scarlet flowers on tall, straight stems. (See Cowee's Scarlet Wonder.)

MARGARET LEWTES-The prize-winning seedling at the Ontario Gladiolus Show in 1923. I would call the color a deep rose lavender. A very few bulbs to offer this year.

MARIE KUNDRED (K) Ruffled-White with a light lilac pink line in the center of the lower petals. Best ruffled white.

MARIETTA (M)-Light salmon. Lower petals shading to deep burnt orange. Large flowers, fine spike. Vigorous variety. Scores very high.

MARY FENNEL (K)-Lavender pink with primrose yellow markings in the lower petals. Excellent cut flower.

MARY S. BURKE (D)-Yellow, overlaid with rose, giving the effect of apricot. A long spike with many flowers opening at once. A wonderful cut flower and very effective in mass. 
MASTERPIECE (K)-Rose red throat lightly marked Amaranth purple. Good form.

MATTHEW CRAWFORD-Large, creamy pink.

MAURICE FULD (Gage)-Beautiful, true pink. Exceptionally large flowers of perfect form.

MIKADO (M)-A novelty. Good plant and spike with large blooms of salmon so heavily flecked and overlaid as to make a unique and almost indescribable flower. Worth while.

MINUET (Col)-Delicate, creamy lavender. Four to six large flowers open at once. Strong grower. The best clear lavender so far.

MISS MADISON (Boynton)-Clear, glowing pink. Large, well placed bloom. A new variety that is fast making friends.

MISS T. ROSE (Fischer)-Creamy yellow and delicate pink. Colored like a Tea rose. Large flowers on a tall graceful spike. A new one of real merit. Strong grower.

MME MAUMENE (Vil)-White with dark garnet throat.

MME MOUNET-SULLY (L)-Milk white with a large carmine blotch. Strong spike with many large flowers open at once.

MONA LISA (K) Ruffled-A very pale rose pink. Very delicate shade. Beautiful.

MONON (K)-Tall, dark rose pink, flecked darker and darker throat. White inner upper throat. Large blooms, long, strong spike.

MOONLIGHT-Large tinted white, exquisite flower and spike. Vigorous plant.

MORNING GLORY (Z)-A deep rose pink of large size. A worth while new one.

MORNING GLORY (Voss)-The improved Schwaban. Colored like Schwaban but earlier and better arranged on the spike.

MRS. DR. NORTON (K)-This beautiful pink and yellow gladiolus is too well known to need description. One of the best.

MRS. F. C. PETERS (Fischer)-Amaranth pink with a purplish blot in the throat. Tall straight spike. Many flowers open at once.

MRS. FRANCIS KING (Coblentz)-Jasper red, throat lighter. Tall spikes, large flowers.

MRS. FRANK MORTON (Gage)-A tall, thrifty variety. The color is best described by a little girl who visited my gardens last year. "See that pretty white one with the pink trimming."

A $\quad 3.50$

A $\quad .30 \quad 3.00$

$\begin{array}{lll}\text { B } & .20 & 2.00\end{array}$

$\begin{array}{lll}\mathrm{A} & .15 & 1.50\end{array}$

$\begin{array}{lll}\text { B } & .10 & 1.00\end{array}$

$\mathrm{A} \quad .50$

$\begin{array}{lll}\mathrm{A} & .25 & 2.50\end{array}$

B $\quad 1.75$

$\begin{array}{lll}\mathrm{A} & .10 & 1.00\end{array}$

B $\quad .75$

$\begin{array}{lll}\mathrm{A} & .10 & .80\end{array}$

B $\quad .50$

A $\quad .25 \quad 2.50$

A $\quad .10 \quad 1.00$

A $\quad .15 \quad 1.50$

$\begin{array}{lll}\mathrm{A} & .10 & .80\end{array}$

B $\quad .60$

$\begin{array}{lll}\mathrm{A} & .15 & 1.25\end{array}$

B $\quad .80$

C $\quad .50$

A $\quad .10$

A $\quad .10 \quad 1.00$

MRS. FRANK PENDLETON (K)-Rose pink with large, rose red blotch. An old favorite.

MRS. H. E. BOTHIN (D)-Ruffled-Light geranium pink; flame scarlet center. Large flower and plant. 
MRS. J. K. ARMSBY (D)-Coral pink, cream throat. speckled with ruby. Tall, very large flowers and many open at once.

MRS. LEON DOUGLASS (D)-The length of spike, together with the size of the flower, makes it perhaps the largest gladiolus in existence. Ground colored begonia rose, flecked deeper. Very much sought after.

MRS. PRESTGARDE (Prest)-White, almost like Europa but a bigger, stronger plant.

MRS. P. W. SISSON (Col)-Crearny light pink. Winner as best seedling at the American Gladiolus Show in New York in 1925. Tall, strong grower, many open. An outstanding variety.

MRS. VON KONYNENBURG-Tall, clear light blue; good propagator; large blooms.

NABOB (M)-Light cerise scarlet; cream colored stripe in all petals. Large, open flowers, tall strong spikes.

NAUTILUS (Col)-White with the very faintest lilac sheen. Large flowers. Nothing could be more beautiful.

NELLIE GRANT (M)-Dark nelrose, very nice spike of large, open flowers. Very beautiful variety. Strong grower.

NEOGA (K) Ruffled-Dark garnet red. Very strong spike. Perhaps the best garden red.

A $\quad 1.00$

A $\quad 3.00$

A $\quad 5.00$

$\mathrm{A} \quad .15$

$\mathrm{A} \quad .15$

$\mathrm{A} \quad .20$

B

$\mathrm{A} \quad .10$

1.00

B

$\mathrm{A} \quad .10$

1.00

NIGHT WINGS (Col) Prim. Hybrid-No hood. Very slender spikes bearing immense, bright red bloom. The large sized flowers are apt to bend the spikes over but they don't break. Excellent for vase or basket.

NINETEEN-TEN ROSE (K)-T'all, strong spike with many large rose pink blooms out at once. Excellent cut flower variety. Very early.

ODIN (Holland)-Deep salmon pink with carmine blotch. Large flowers. Early.

OLD GLORY (K)-Dark red striped all over with white.

ORANGE QUEEN (Pfitzer) P. G.-A coppery orange with a very small red mark deep in the throat.

PARAMOUNT (K)-Pale rose pink flecked deeper. Strong plant with many large flowers.

PARLIAMENT (Kel)-Large, clear pink flowers of wonderful form. Slight throat markings. Very nice.

PASSION FLOWER (M)-Pure cardinal red. Sprinkling of white in the throat. Lower petals dark garnet. Large flowers. Fine spikes and early.

PEACH ROSE (K)-Deep rose pink blotched rose red. Very beautiful.

PEARL OF DAWN (K)-Beautiful ruffled pink. A .15 Tall and strong grower.

$\begin{array}{lll}\mathrm{A} & .10 & .80\end{array}$

B $\quad .50$

$\begin{array}{lll}\mathrm{A} & .10 & 1.00\end{array}$

$\mathrm{A} \quad .20$

$\mathrm{A} \quad .25$

$\mathrm{A} \quad .25$

$\mathrm{A} \quad .10$

$\mathrm{A} \quad .10$

B 
PEERLESS (M)-Pale lavender pink with feather of purple in the throat. Tall, straight spike; many flowers open at once.

PELLETIER D'OISY (L)-The green gladiolus. A distinct novelty.

PERSIA-So dark a red that it's almost black. Good sized flower on a good spike. Nearly like, if not identical with, Arabia.

PFITZER'S TRIUMPH (Pfitzer)-Immense flowers of orange salmon with small, velvet red blotch. Very showy. A sensational Glad.

PHENOMENON (Pfitzer)-Soft salmon pink with cream yellow lip. Many opened. Early and a good propagator.

PINK PERFECTION-Alizarine pink. Large, open flowers on long, crooked spikes. An old favorite.

POLI NEGRI (D)-Apricot, darker on the outer edges. Ruffled. A paler and prettier Jack London.

POLAR STAR (M)-Cream white, large flowers and many out at once. One of the good ones.

POLLYANNA (Prest)-Clear, rich golden yellow. Many medium sized blooms open at once. A really beautiful yellow.

PRIDE OF LANCASTER (K)-Ruffled-Shrimp pink, suffused peach red. Rather compact spike of very nice bloom.

PRIDE OF MELROSE (Liable)-Deep rose with a white throat. A glorified Rosella.

PRIMULINUS SPECIES-The original wild Primulinus. Small, deep yellow blooms. Hooded. Of value only as a novelty, and in combination with the violet or blue Glads.

PRINCE OF INDIA-Madder; the original smoky pink and still good enough to be a frequent winner in any other color classes.

PRINCE OF WALES-Strawberry pink. Many large flowers well arranged on a good spike. Very early.

PRINCESS-Dainty shaded cream and pink with red feather in the throat. Tall, strong grower; attractive. Not seen in many gardens. A really beautiful Glad.

PURPLE GLORY (K)-Large, dark velvety maroon. A wonderful variety. Rather slow to increase.

QUEEN ESTHER (M)-A brilliant purple and gold gladiolus. Large flowers, many out.

A $\quad 1.00$

$\mathrm{A} \quad .25$

2.50

B

1.75

A

5.00

A

3.00

B

2.00

C

1.50

A

$\mathrm{A} \quad .10$

1.00

B

A

B

A

1.50

.15

1.00

A

A

A

A $\quad .20$

B $\quad .15$

$\mathrm{A} \quad .10$

.75

B

A $\quad .15$

1.50

B $\quad .10$

1.00

A

$\mathrm{A} \quad .15$

1.50

B

1.00

RED CROSS (Meader)-Excellent, deep red.

RED EMPEROR (Groff)-Bright nopal red. Enormous flowers on strong spikes. Early

REMEMBRANCE (K) Ruffled-Rose-doree, lighter toward the throat. Pomegranate purple blotch. Large flowers and strong grower.

$\mathrm{A} \quad .25$

$\mathrm{A} \quad .10$

$\mathrm{A} \quad .10$ 
RICHARD DIENER (D)-Pale geranium pink, lightly flecked rose-doree blotched Barium yellow. Excellent spike of large, well ruffled flowers.

ROI ALBERT (Velthaise)-A smoky pink; hard color to describe. A spike of Roi Albert was the sensation of the show in Rochester in 1926. Tall spike, large, wide open flowers; well placed and a good number out. One of the very best of the smoky ones. Strong grower. Average to . good increase.

ROMANCE (K)-Rose pink with all the petals edged steel blue. Tall spike with many large flowers open at one time. A very distinctive and beautiful variety.

ROSE ASH (M)-Corinthian red, shading to ashes of roses on the outer edge. Large flowers on tall spikes.

ROSE GLORY (K) Ruffled-A rose pink, shading to deeper in the throat. About the best of its color.

ROSEMARY (Bales)-Something different. White with fine stippling of lavender rose over the entire bloom. The color goes right through, making the back of the petals the same as the front. No other gladiolus anything like it.

ROSENEL (M)-Clear nelrose. Large flowers, nice spike and wonderful color.

\begin{tabular}{lll} 
& 1 & 12 \\
$\mathrm{~A}$ & \multicolumn{1}{l}{.15} & 1.50 \\
$\mathrm{~B}$ & & 1.00
\end{tabular}

A $\quad 2.50$

B $\quad 2.50$

$\mathrm{A} \quad .15$

$\mathrm{A} \quad .10 \quad .85$

B $\quad .60$

$\mathrm{A} \quad \mathbf{1 5} \quad 1.50$

B $\quad 1.00$

A $\quad 25 . \quad 2.50$

B $\quad 1.50$

RUFFLED AMERICA (K) Ruffled-Soft lavender pink.

SALMON BEAUTY (K) Prim. Hybrid-Large, strong plant and one of the best salmon Prims.

$\mathrm{A} \quad .15 \quad 1.50$

B $\quad 1.00$

$\mathrm{A} \quad .15 \quad 1.50$

B $\quad 1.00$

$\mathrm{A} \quad .10 \quad .80$

$\mathrm{B} \quad .50$

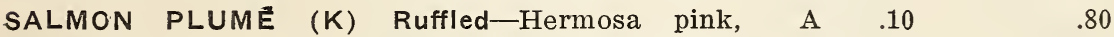
strong spike, large flowers; wonderful foliage. B $\quad 50$ Always good.

SANS PARIELL (L)-Clear, deep pink, white in A .50 $\begin{array}{lllll}\text { the throat. Large blooms on a tall spike. A } & \text { B } & .35 & 3.50\end{array}$ very beautiful gladiolus.

SARAH BERNHARDT (L)-Beautiful pink with dark throat blotch. New.

$\mathrm{A} \quad .20$

SCARLANO (K) Ruffled-Bright orange red. Fine A $\quad .10$ spike and flower.

SCARLET PRINCEPS-Strong spikes of massive, scarlet red blooms. A good number out. Consistent winner at the shows.

SELECTION (M)-White ground, edges tipped lavender. Good sized flowers, star type.

SHEILA (Col)-Light coral red; lighter throat with light pomegranate purple pencilings. Large, wide open flowers on an almost perfect spike. Early. 
SHELL PINK (K) P. G. Not Hooded-LaFrance

A $\quad 1.15$

pink, a little deeper on the edges of the petals and paler in the throat. A large spike with many blooms open at once.

SHENENDOAH (G)-Rated a super-Glad by Gersdorf. Deep pink, large.

SIRIUS (K) Prim. Hybrid-Beautiful salmon pink. A low growing Glad. Many large flowers out. Excellent in the garden and as a cut flower as well.

SNOW GLORY (K) Ruffled-Pure white with violet feather on lower petals.

SOPHIA FISCHER (Fischer)-Large flowers of a beautiful soft pink with a deeper blotch. Tall, strong stem. First prize seedling at the American Gladiolus Society's exhibition in Boston. Really good.

SOUVENIR (Graveau)-Pure golden yellow Prim. Hybrid. Tall, good sized blooms and possibly the purest yellow yet brought out.

SUMMER BEAUTY (K)-Beautiful, soft pink. Not as strong a grower as some but when it does come right, worth all the effort.

SUMMER DREAM (M)-Light American Beauty pink, shading to white in the throat. Lower petals largely white.

SUNNYMEDE (Fischer)-Orange yellow with a deep red blotch. Large, well opened blooms. A most distinctive and beautiful variety. Don't miss having Sunnymede.

SUPERBA (Col)-Giant carmine scarlet. Wonderful spikes of many large, wide open flowers. Winning seedling at the A. G. S. Show in Grand Rapids. A real Glad.

SWEET LAVENDER (Col)-Light lavender with purple blotch. Excellent plant and large flowers. One of the very earliest.

TARO (K)-Strong spike and mammoth flowers of American Beauty rose color. Exceptionally good.

THEDA BARA (Hasg)-A beautiful tinted white. Many large flowers upon a spike. not always straight.

THE PILOT (M) Ruffled-Rose pink, blending to white. Nice spike of large, well opened flowers with a little different arrangement of color than usually seen.

TIFFANY (Brown)-A good commercial white. Excellent substance and a good propagator.

A $\quad .20$

$\mathrm{A} \quad .10$

B

B

1.75

1.00

$\mathrm{A} \quad .10$

B

C

$\mathrm{A} \quad .10$

1.00

B

TITANIC (Hoeg)-Lilac purple, self. Large, wide open flowers. An excellent variety.

TOPAZ (K) Prim. Hybrid. Hooded-Salmon pink. A 
TWILIGHT (K)-Creamy white, flushed pink, with a pink and yellow throat. One of the nicest of the newer Kundredi.

TWIN FIRES (Fischer)-Another new one that is bound to be widely grown. Pure pink lower petals blotched yellow with two distinctive bright scarlet spots which give it its name. One you should certainly grow.

TYCKO ZANG (Austin)-Immense salmon pink with white throat. Tall, strong grower. Excellent foliage and a good propagator.

TYRIAN BEAUTY (K) - Giant plant and spike with many large flowers of Tyrian rose color. Nothing to compare with it in this color.

UNCLE SAM (Liable)-A giant plant with large flower. Early and dependable. Rose pink predominating color. A worth while new one.

VANITY (Bill) Prim.-LaFrance pink over cream ground. Exceptionally tall spike.

VEILCHENBLAU (Pfitzer)-Tall, dark blue; the best of its color.

VIOLA (Holland)-White with a large blotch of violet blue. Perhaps as nearly blue as you ever get in a Glad. Sometimes this color blotch is lightly suffused over the entire bloom. Strong grower and excellent flower spike.

VIOLET BEAUTY (K)-Mallow purple, shading to light mallow purple, blotched darker. Good plant and good bloom. Excellent cut flower.

VIRGINIA HALE (K)-Soft, creamy pink, brighter toward the edge. Very beautiful.

WABAN-Very deep pink with blotch. Very large flowers. Early.

WAR (Groff)-Deep, brilliant red. One of the very best reds.

W. H. PHIPPS (D)-LaFrance pink overlaid with light salmon rose. Lighter toward the center. Large flowers and a great many open at once.

WHITE PIGEON (K)-Large, pure white.

WILLIAM KENT (D)-Ivory yellow, suffused with rose pink at edges. Throat buff yellow flaked carmine. Well ruffled; many open and a very beautiful variety.

WILLIS E. FRYER-Mallow purple overlaid Rhodamine purple; outer edges aster purple. A little yellow in the throat. Strong grower; large flowers of wonderful texture.

YELLOW PRIZE (M)-Metzner's best yellow.

YELLOW TREASURE (Austin)-Medium sized, ruffled yellow. Evidently has Primulinus blood but doesn't appear like one. Excellent for vase

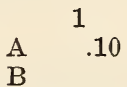

12

B

10

1.00

A $\quad .25$

2.50

1.75

1.00

A $\quad .40$

4.00

3.00

$\mathrm{A} \quad .10$

1.00

A $\quad .35$

$\mathrm{A} \quad .10$

1.00

B

A $\quad 2.50$

$\mathrm{A} \quad .15$

A $\quad .10$

1.00

.70

$\mathrm{A} \quad .25$

A $\quad .10$

$\mathrm{A} \quad .10$

A $\quad .40$

4.00

2.50

1.75

A $\quad .15$

1.50

A $\quad .75$

A $\quad .15$

B

1.00

A $\quad .35$

$\mathrm{A} \quad .10$

B or baskets. An attractive flower. 
YOLO' (M)-Bright cerise, shading to scarlet; lower petals tinted cream with a cardinal blotch.

YOSEMITE (M) Ruffled-Rich salmon rose. Very nice.

1

A

.15

1.50

YOUELL'S FAVORITE (K) Ruffled-Lavender pink. Large plant and flower.

$\begin{array}{lll}\mathrm{A} & .20 & 2.00\end{array}$

B $\quad 1.50$

$\mathrm{A} \quad .10 \quad .80$

B $\quad .60$

ZYPHER'S GIFT (M)-Light rose pink over white

$\mathrm{A} \quad .15 \quad 1.50$
ground, shading to dark rose pink on the outer part of petals. Large, round, petaled blooms. 


\section{WHOLESALE PRICE LIST}

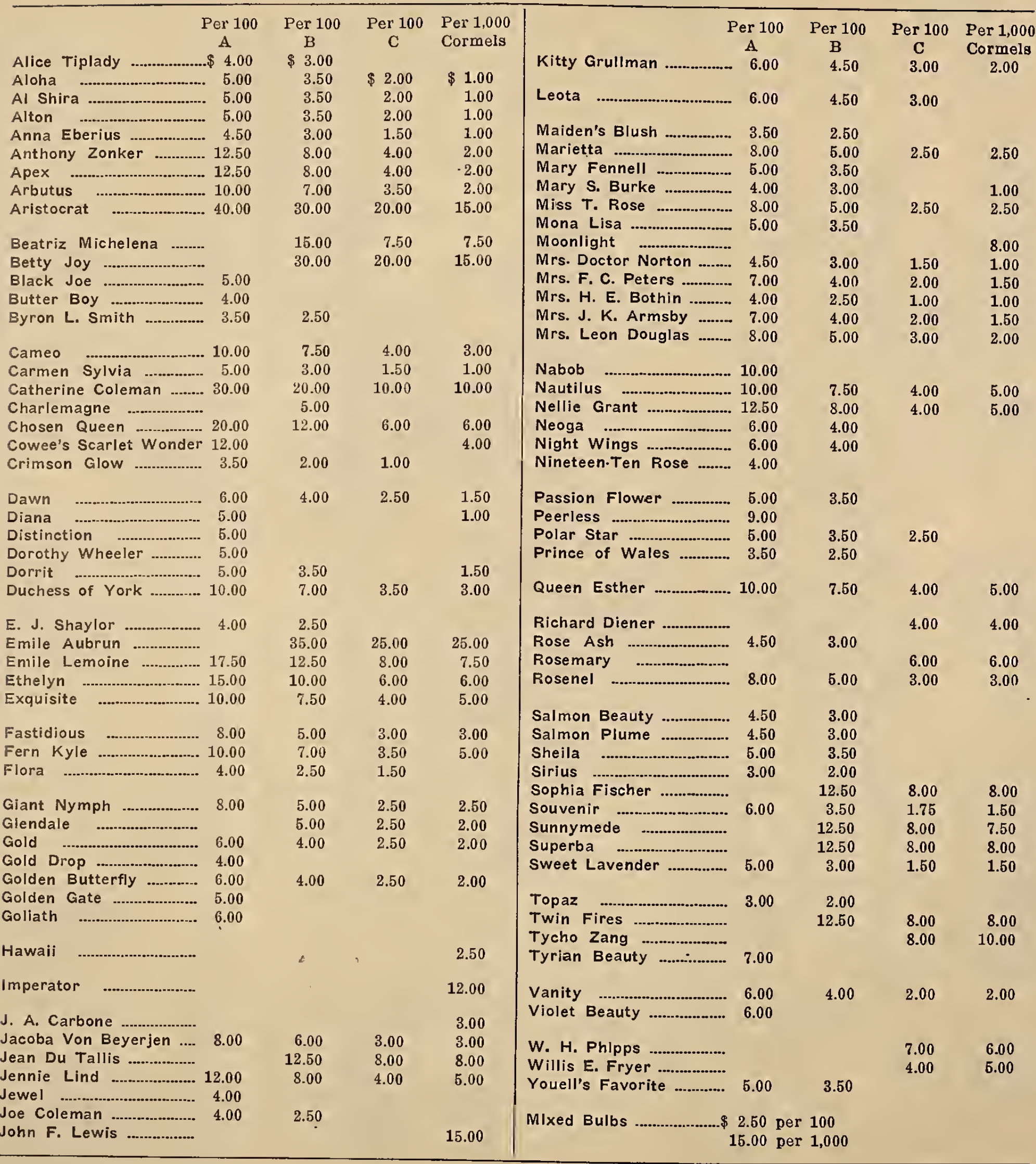



